\title{
The Development of Speaking Skill's Instrument in Elementary School with Rasch Model Analysis
}

\author{
Nandang Rusmana ${ }^{1, *}$, Dodi Suryana ${ }^{1}$, Heni Surya Kurniasih ${ }^{2}$, Nuzsep Almigo ${ }^{3}$ \\ ${ }^{1}$ Department of Guidance and Counseling, Universitas Pendidikan Indonesia, Indonesia \\ ${ }^{2}$ Department of Primary School Teacher Education, Universitas Pendidikan Indonesia, Indonesia \\ ${ }^{3}$ Department of Educational Studies, Universiti Pendidikan Sultan Idris, Malaysia
}

Received January 9, 2020; Revised March 9, 2020; Accepted May 13, 2020

Copyright $\mathrm{O} 2020$ by authors, all rights reserved. Authors agree that this article remains permanently open access under the terms of the Creative Commons Attribution License 4.0 International License

\begin{abstract}
This study was motivated by the incomprehension of some elementary school teachers about topic learning and how to teach the topic learning of speaking skill in elementary school students. This study aims to evaluate speaking skill of elementary school students through the development of speaking skill instruments and analyzed in Rasch model. The study employed descriptive analysis with a cross-sectional design. The participants of the study were the students of a State Elementary School in Indonesia consisting of 43 students of grade VI at Layungsari Elementary School and 47 students of grade VI at Balandongan elementary school. The results of the analysis show that the construct of the instrument used measures one variable, namely is speaking skill of elementary school students and from 90 participants, 14 people $(15.5 \%)$ are included in the high ability category, the category there are 63 moderate abilities (70\%), and 13 (14.4\%) low ability categories.
\end{abstract}

Keywords Speaking Skill, Rasch Models, Development of Instruments

\section{Introduction}

Humans are social creatures that can not be separated into individual communications with other, communication activities often carried out through talking so every individual must have speaking skill to be able to express thoughts, feelings ably. In everyday life of humans are inseparable with activities of talking and listening a topic appropriat the context and situation. Elementary school students had been able to speak, able to convey wants, wishes, and feelings. Even though elementary school students are still at an early age, children as social beings must be willing to assist, assistance can be in the form of assistance to their families, groups of friends even to people they do not know. Thus elementary school students must have good speaking skill as social beings [1]. However, most students have not been able to speak in public. Even if he is instructed to speak in class they are still shy. In general, they are only able to talk with close friends only, or with people who have become accustomed he/she spoke [2]. If they are still experiencing difficulties in interpersonal communication in their environment they can be ignored, rejected, not accepted by the environment, it is increasingly difficult for wider interaction. Interpersonal communication can occur when there is a dialogical communication process between the communicator and the communicant so that interaction occurs [3]. Inability to speak in public and formal situation was also experienced by adults such as teachers, preachers, and speakers who are not yet skilled in speaking well, such as preachers and teachers are still causing disinterest for listener and does not understand message delivered while the goal of learning to speak in schools; students can communicate in various situations using spoken language properly in conveying thoughts, opinions, feelings, experiences so that they can interact socially with the community [4].

Their speaking skill in a person will allow him to deliver, share, exchange information, thoughts, opinions, and feelings with others in various situations with anyone, anytime and anywhere.

Speaking is an activity that someone uses to communicate with others [5]. Communication process includes the transfer of messages from one party to another to exchange information such as opinions, intentions and messages, disclosures and other feelings verbally [6], [7]. Speaking skill not only use the knowledge of language but also ability to process information and language appropriate to topic and understand messages to be delivered [8], [9]. 
Ability to speak one's not obtained simultaneously perfect but developed gradually from childhood to adulthood. Speaking skill can be trained from an early age in primary school for elementary school the initial impetus to improve her/his skill through active participation in the class, which express themselves in group activities so that incidence of interaction between group members [10], [11]. Also, school is a new social situation for students so it is important for adult control such as a teacher for students to find identity and self-preservation [12]. But learning to speak is still negligible at elementary school level because the majority of primary school teachers did not know what to teach and how to teach speaking skill in students [4]. Based on this required the development of speaking skill tested instrument validity and results can be used as input on the evaluation of students' speaking skill.

Usually, teachers are evaluating students' abilities based on an already existing section in the student worksheet are distributed to schools and a small portion that makes its section then describes the outcome assessment indirectly from raw data [13]. Raw data not been treated has a weakness, that has meaning qualitatively weak because it depends on percentage of correct answers and number of questions, not able to demonstrate the ability of a person to a particular task, percentage of correct answers is not always linear, not the result of measurement, but number of correct answers of questions that done and is still preliminary information summary of data is numeric [14].

Raw data needs to be processed using a representative analysis tools to produce accurate and reliable data. Based on this research using Rasch model for analyzing, the raw data result development testing instrument speaking skill in elementary school students. Rash model is an application that utilizes a mathematical model and transform the raw scores into preparations which can provide valid information, accurate and construct maps presented earlier test developers so that more objective assessment and can reveal the accuracy of test developed by measured [14].

In this study, the authors developed instrument with due regard to concept of speaking skill through existing theories, analyze the needs of the speaking skill through some literature that produces these aspects and indicators of speaking skill, then reconstructed into questions with answer choices using rating scale. Instruments that have been made later in the trial, are reflected and validated using a model rash. As did Kurniawan in development of the instrument through steps (a) analysis of problems and needs, (b) review of literature, (c) design of product (d) validity, (e) trial practitioner [15], but in this study validated using Rasch models.

\section{Research Methodology}

This study approach used in this study was a cross-sectional study, study entire variable observed and measured at same time of the study [16]. The study aims to determine speaking skill of elementary school students in Tasikmalaya, Indonesia with independent variables in this study include student characteristics (gender, school of origin) and dependent variable in this study is speaking skill.

This study uses the development of speaking skill are then tested instruments to students through self-assessment The participants of the study were the students of a State Elementary School in Indonesia consisting of 43 students of grade VI at Layungsari Elementary School and 47 students of grade VI at Balandongan elementary school. The raw data is then verified and processed into data ready to be processed using Rasch models. Rasch model is a model of the measurement process raw data scores of nominal and ordinal scales [17]. Rasch models can provide a solution the limitations of classic models such as classical model that reliability depends on the sample [18].

Table 1. Research samples

\begin{tabular}{|c|c|c|c|}
\hline \multirow{2}{*}{ School Name } & \multicolumn{2}{|c|}{ Population } & \multirow{2}{*}{ Amount } \\
\cline { 2 - 3 } & Male & Female & \\
\hline Balandongan Elementary School & 18 & 29 & 47 \\
\hline Layungsari Elementary School & 26 & 17 & 43 \\
\hline Amount & 44 & 46 & 90 \\
\hline
\end{tabular}

\section{Results}

Validity and reliability of the instrument is very important to look accuracy questionnaire[19]. To test reliability and validity of instrument can be seen from the following table as a summary statistic,

Table 2. Summary Statistics

\begin{tabular}{|c|c|c|c|c|}
\hline & Mean & Separation & Reliability & Cronbach Alpha \\
\hline Person & 0,87 & 1,30 & 0,63 & \multirow{2}{*}{0,68} \\
\hline Item & 0,00 & 3,48 & 0,92 & \\
\hline
\end{tabular}

Reliability Person value of 0.63 as an indicator of the consistency of the respondent's answer, it shows the overall reliability of respondents categorized as weak. While the Item Reliability of 0.92 as an indicator of quality of grain items in an instrument classified as category nice so reliable for use in this study, Cronbach Alpha value, which represents the interaction between person with a grain of overall item, 0,68 categorized enough.

Validity of respondents can be seen from person measure that shows average score of all participants in working on a grain item of data disclosure instrument of elementary school students in speaking skill. Validity of instrument is to see how far the measuring instrument can measure the attributes that should be measured [20]. Average value is 0.87 logit person, this shows the total respondents have a tendency skilled in speaking. While the views of value of separation are calculated with more precision through the formula: $\mathrm{H}=\frac{\{(4 \times \text { separation })+1\}}{3}$ so that value of separation for persons was 2.06 rounded to 2 . 
This implies that study participants to have diversity capability can be categorized into two groups: skilled and unskilled in speaking.

Validity of items can be seen from average value of logit items. In this study had a logit item average is 0.0 logit, which shows the overall instrument can measure. While separation of items is 4.97 rounded to 5 , which means that study participants have diversity of capabilities that can be categorized into five groups, from the group is very easy, fairly easy, easy, difficult and very difficult.

Reliability instrument in measuring exactly should be measured can be evaluated through the test unidimensionalitas [21]. This analysis instrument using Output Table 3 with regard to value Raw variance explained by measures and Unexplained variance in 1st to 5th contrast. Unidimensionalitas measurement can be proved if Raw variance explained by measures of $\geq 20 \%$ (Note: The general criterion of interpretation is: enough if $20-40 \%, 40-60 \%$ good if, and nice if above $60 \%$ ) and if Unexplained variance in 1 st to 5 th contrast of residuals each $<15 \%$.

Table 3. Unidimensionalitas

\begin{tabular}{|c|c|c|c|}
\hline $\begin{array}{c}\text { Raw unexplained } \\
\text { variance }\end{array}$ & Eigenvalue & Observed & Expected \\
\hline $\begin{array}{c}\text { nexplained variance in } \\
\text { 1st }\end{array}$ & 2.8725 & $13.7 \%$ & $19.2 \%$ \\
\hline $\begin{array}{c}\text { Unexplained variance } \\
\text { in 2nd }\end{array}$ & 2.0292 & $9.7 \%$ & $13.5 \%$ \\
\hline $\begin{array}{c}\text { Unnexplained variance } \\
\text { in 3rd }\end{array}$ & 1.5896 & $7.6 \%$ & $10.6 \%$ \\
\hline $\begin{array}{c}\text { Unexplained variance } \\
\text { in 4th }\end{array}$ & 1.4049 & $6.7 \%$ & $9.4 \%$ \\
\hline $\begin{array}{c}\text { Unexplained variance } \\
\text { in 5th }\end{array}$ & 1.0739 & $5.1 \%$ & $7.2 \%$ \\
\hline
\end{tabular}

Raw data analysis results show the variance explained by measures of $28.5 \%$ is sufficient. While Unexplained variance in 1 st to 5 st contrast of residuals, respectively $13.7 \%, 9.7 \%, 7.6 \%, 6.7 \%$ and $5.1 \%$. It appears that each of less than $15 \%$. Thus constructs used instruments actually measure variables: Speaking Skill Elementary School Students.

To view the suitability of grain with a model (item fit) to clarify whether grain items in normal functioning instrument in measuring so that no misconceptions on self Elementary School students to the instrument Speaking Skill. It stretcher may be explored based on the data in Table 4: Item Fit Order which OUTFIT column mean square (MNSQ), Z-standard OUTFIT (ZSTD), and point correlation measure (PT MEASURE CORR). Criteria for checking suitability of item (item fit) or observational data are inconsistent with outlier or misfit. According Booner et al. (2014) are as follows: (1) MNSQ OUTFIT Values greater than 0.5 and less than 1.5 and has come closer to 1 the better; (2) Value OUTFIT ZSTD greater than -2.0 and smaller than +2.0 come closer to 0 the better; and (3) the value of PT MEASURE CORR more than 0.4 and less than 0.85 . An item can be considered fit if the item meets at least one of three criteria.
Table 4. Item Fit

\begin{tabular}{|c|c|c|c|c|c|}
\hline \multirow{2}{*}{$\begin{array}{c}\text { Entry } \\
\text { number }\end{array}$} & \multirow{2}{*}{ Measure } & \multicolumn{2}{|c|}{ OUTFIT } & \multirow{2}{*}{$\begin{array}{c}\text { PT } \\
\text { Measure } \\
\text { Corr }\end{array}$} & \multirow{2}{*}{ Item } \\
\hline & & MNSQ & ZSTD & & \\
\hline 5 & 0.34 & 1.48 & 2.81 & 0.54 & P5 \\
\hline 10 & 0.38 & 1.38 & 2.27 & 0.49 & $\mathrm{P} 10$ \\
\hline 2 & -0.13 & 1.35 & 2.34 & 0.49 & P2 \\
\hline 15 & 0.79 & 1.34 & 1.98 & 0.34 & P15 \\
\hline 3 & -0.15 & 1.28 & 1.92 & 0.58 & P3 \\
\hline 4 & -0.86 & 1.11 & 0.77 & 0.21 & $\mathrm{P} 4$ \\
\hline 7 & -0.85 & 1.08 & 0.63 & 0.31 & $\mathrm{P} 7$ \\
\hline 13 & -0.23 & 0.99 & -0.01 & 0.40 & $\mathrm{P} 13$ \\
\hline 14 & 0.43 & 0.86 & -0.89 & 0.34 & P14 \\
\hline 9 & -0.07 & 0.82 & -1.32 & 0.38 & P9 \\
\hline 12 & $-0,03$ & 0.80 & -1.47 & 0.41 & P12 \\
\hline 1 & 0.64 & 0.74 & -1.77 & 0.27 & $\mathrm{P} 1$ \\
\hline 6 & -0.21 & 0.74 & -2.05 & 0.49 & P6 \\
\hline 11 & -0.56 & 0.63 & -3.21 & 0.49 & P11 \\
\hline 8 & 0.51 & 0.37 & -5.39 & 0.67 & P8 \\
\hline
\end{tabular}

Based on criteria-1 known there is one item that misfit, the number 8 which has a value of 0.37 MNSQ OUTFIT. According to the standard- 2 there are 6 items that misfit, the numbers 5, 10,6, 2, 11 and 8. Meanwhile, based on the criteria-3 that as many as 9 points an item has a value of PT MEASURE CORR more than 0.4 and less than 0.85 . There are six items, namely number $15,4,7,14,9$, and one which has a value of PT MEASURE CORR 0.25 , or less than 0.4 so stated outfit. Referring to the views Booner et al. (2014), the 15-point item no item stated misfit. If no item misfit means there should be no question removed or replaced.

Therefore, to determine whether participants understand the difference in the scale of choice answers 1,2, 34 and 5 rating scale can through diagnostic. Rating scale is based assessment of certain scale to see performance[22]. Differences answers understood by the respondent if the observed average value and andrich threshold in Table 5 shows the suitability and equally increased.

Table 5. Diagnostic Rating Scale

\begin{tabular}{|c|c|c|}
\hline Catergory Label & Observed Average & Andrich Threshold \\
\hline 1 & -0.01 & None \\
\hline 2 & 0.24 & -1.23 \\
\hline 3 & 0.58 & -1.40 \\
\hline 4 & 1.05 & 1.22 \\
\hline 5 & 1.45 & 1.42 \\
\hline
\end{tabular}

The analysis shows there is a match less improvement in both of these values along with increased rating scale. Thus it can be stated that the different possible answers 1,2, 4, and 5 it can be understood by the participants, while the third answer choice is less understandable or confusing students. It is, therefore, suggested alternative answers, not 5 but simply four only. 
Table 6. Item Measure

\begin{tabular}{|c|c|c|}
\hline Entry Number & Measure & Item \\
\hline 15 & 0.79 & P15 \\
\hline 1 & 0.64 & $\mathrm{P} 1$ \\
\hline 8 & 0.51 & P8 \\
\hline 14 & 0.43 & P14 \\
\hline 10 & 0.38 & P10 \\
\hline 5 & 0.34 & P5 \\
\hline 12 & -0.03 & $\mathrm{P} 12$ \\
\hline 9 & -0.07 & P9 \\
\hline 2 & -0.13 & $\mathrm{P} 2$ \\
\hline 3 & -0.15 & $\mathrm{P} 3$ \\
\hline 6 & -0.21 & P6 \\
\hline 13 & -0.23 & P13 \\
\hline 11 & -0.56 & P11 \\
\hline 7 & -0.85 & P7 \\
\hline 4 & -0.86 & $\mathrm{P} 4$ \\
\hline MEAN & 0.00 & \\
\hline SD & 0.49 & \\
\hline
\end{tabular}

The difficulty level of the item can be examined in Table
6: Item Measure. From the table, the standard deviation is 0.49 . The Standard deviation value when combined with the average value logit then the level of difficulty of the items can be grouped into categories very difficult (larger $+1 \mathrm{SD})$, difficult category $(0.0$ logit $+1 \mathrm{SD})$, easy categories $(0.0$ logit - $1 \mathrm{SD})$, and very easy category (less than $-1 \mathrm{SD}$ ). Thus, the limit value for a very difficult category is more than $0.49,0.00$ difficult category up to 0.49 , the category is 0.0 to -0.49 and very easy categories is less than -0.49 .

By looking at the logit value of each item in Table 6 column item Measure, in a sequence based on the difficulty level (of grain items hardest to easiest) note there are 3 items included a very difficult category, the item number P1, P8, P15. Difficult category, there are three items, namely the number P14, P10, P5. Easy category, there are six items, namely $\mathrm{P} 12, \mathrm{P} 9, \mathrm{P} 2, \mathrm{P} 3, \mathrm{P} 6, \mathrm{P} 13$. While very easy category 3 items, the number P11, P7, P4.

Spreading grain items and skill of elementary school students based map analysis test wright (person-item map).

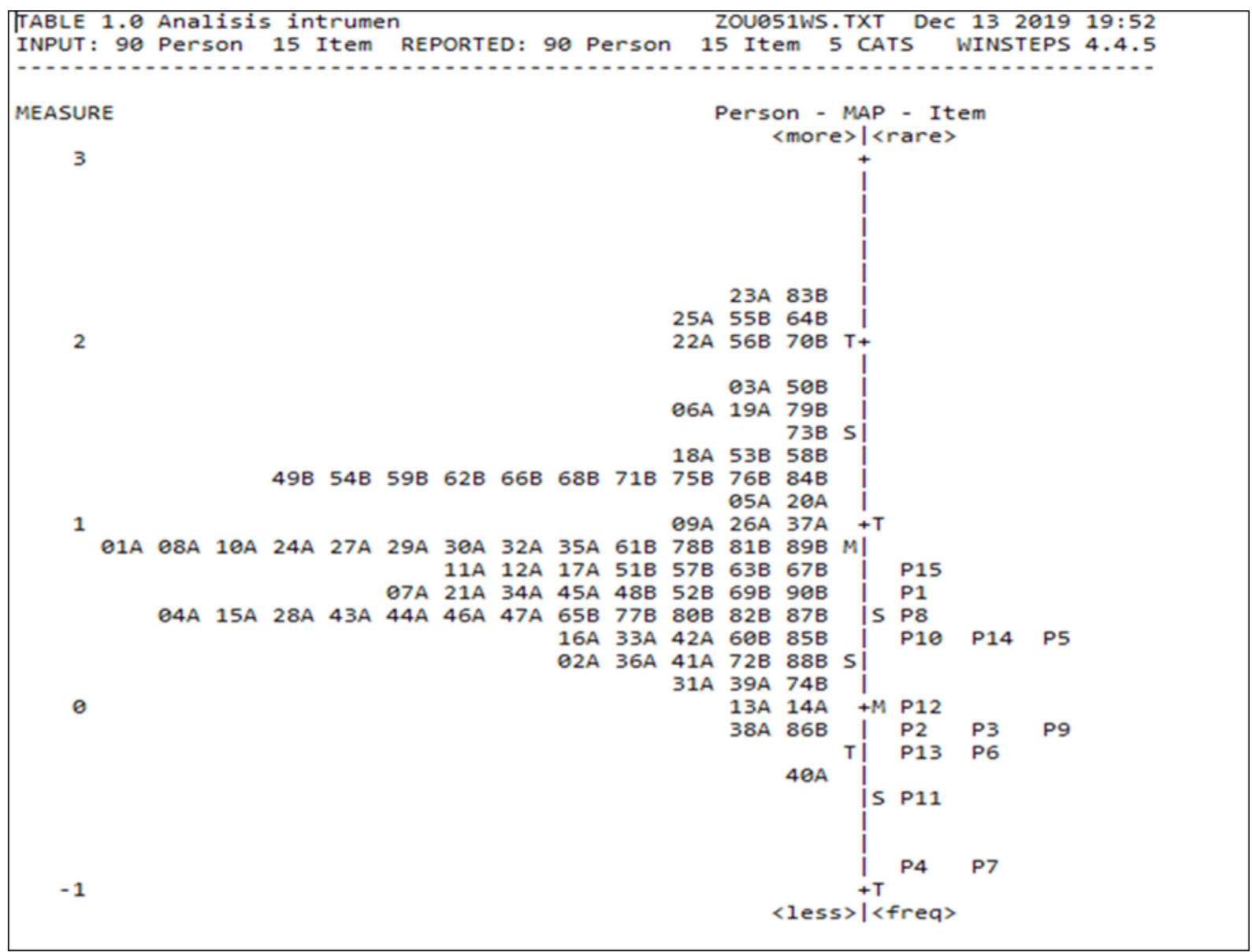

Figure 1. Map Wright (person-item map) 
It can be seen from the left in the wright map shows the distribution of data based on the order of students who have the skill to speak of the highest of $23 \mathrm{~A}$ and $83 \mathrm{~B}$ to the students who have the skill to its lowest speaks 40A. While the right side shows the distribution of the data indicator speaking skill of the most difficult that item easiest P15 and P4 and P7.

The results of the analysis wright map show 45 of the 90 students $(50 \%)$ of primary school students in Tasikmalaya, Indonesia have difficulty speaking skill over 15 indicators of speaking skill. This means that 45 of these students have no difficulty in speaking by item 15 . They are skilled spoke with 15 indicators of well-defined.

The average value of items logit is 0.0 logit, while averaging logit person is +0.87 logit. This shows that the average achievement of students in speaking skill are above the average standard level of difficulty skilled speak. There are 85 students $(94.4 \%)$ having an average attainment skilled in speaking are above the average level of standard difficulty speaking skill. Item P12 (I'm preparing a message to be delivered before talk (think/create streaks)) that are in the 0.0 logit meaningful This item has an average difficulty level and there are 2 students $(2.2 \%)$ having the mean achievement average equivalent to the average level of difficulty speaking skill items. There are 3 students (3.3\%) who have difficulty achieving the standard below average speaking skill.

Table 7. Person Measure

\begin{tabular}{|l|l|}
\hline Measure & Person \\
\hline 2.21 & $23 \mathrm{AP}$, 83BL \\
\hline 2.07 & $25 \mathrm{AP}, 55 \mathrm{BP}, 64 \mathrm{BP}$ \\
\hline 1.95 & $22 \mathrm{AP}, 56 \mathrm{BL}, 70 \mathrm{BP}$ \\
\hline 1.72 & $03 \mathrm{AL}, 50 \mathrm{BL}$ \\
\hline 1.61 & $06 \mathrm{AL}, 19 \mathrm{AL}, 79 \mathrm{BP}$ \\
\hline 1.51 & $73 \mathrm{BL}$ \\
\hline 1.41 & $18 \mathrm{AL}, 53 \mathrm{BP}, 58 \mathrm{BP}$ \\
\hline 1.31 & $49 \mathrm{BP}, 54 \mathrm{BL}, 59 \mathrm{BL}, 66 \mathrm{BL}, 68 \mathrm{BL}, 76 \mathrm{BL}$ \\
\hline 1.21 & $62 \mathrm{BP}, 71 \mathrm{BL}, 75 \mathrm{BL}, 84 \mathrm{BL}$ \\
\hline 1.11 & $05 \mathrm{AL}, 20 \mathrm{AL}$ \\
\hline 1.01 & $09 \mathrm{AL}, 26 \mathrm{AP}, 37 \mathrm{AL}$ \\
\hline 0.92 & $08 \mathrm{AL}, 10 \mathrm{AL}, 24 \mathrm{AP}, 27 \mathrm{AP}, 30 \mathrm{AP}, 32 \mathrm{AP}, 35 \mathrm{AL}, 89 \mathrm{BL}$ \\
\hline 0.82 & $01 \mathrm{AP}, 29 \mathrm{AP}, 61 \mathrm{BL}, 78 \mathrm{BL}, 81 \mathrm{BL}$ \\
\hline 0.73 & $11 \mathrm{AL}, 12 \mathrm{AL}, 17 \mathrm{AP}, 51 \mathrm{BP}, 57 \mathrm{BL}, 63 \mathrm{BL}, 67 \mathrm{BP}$ \\
\hline 0.63 & $07 \mathrm{AL}, 21 \mathrm{AP}, 34 \mathrm{AP}, 45 \mathrm{AP}, 48 \mathrm{BP}, 52 \mathrm{BP}, 69 \mathrm{BL}, 90 \mathrm{BL}$ \\
\hline 0.54 & $04 \mathrm{AP}, 28 \mathrm{AP}, 43 \mathrm{AP}, 44 \mathrm{AP}, 65 \mathrm{BL}, 77 \mathrm{BP}$ \\
\hline 0.44 & $15 \mathrm{AP}, 46 \mathrm{AP}, 47 \mathrm{AP}, 80 \mathrm{BP}, 82 \mathrm{BP}, 87 \mathrm{BP}$ \\
\hline 0.35 & $16 \mathrm{AP}, 33 \mathrm{AL}, 42 \mathrm{AP}, 60 \mathrm{BL}, 85 \mathrm{BL}$ \\
\hline 0.25 & $02 \mathrm{AP}, 36 \mathrm{AL}, 41 \mathrm{AP}, 72 \mathrm{BL}, 88 \mathrm{BL}$ \\
\hline 0.15 & $31 \mathrm{AP}, 39 \mathrm{AL}, 74 \mathrm{BP}$ \\
\hline 0.06 & $14 \mathrm{AP}$ \\
\hline-0.04 & $13 \mathrm{AP}$ \\
\hline-0.13 & $38 \mathrm{AL}, 86 \mathrm{BL}$ \\
\hline-0.41 & $40 \mathrm{AL}$ \\
\hline Mean & 0.87 \\
\hline $\begin{array}{l}\text { Standar } \\
\text { Deviasi }\end{array}$ & 0.58 \\
\hline & \\
\hline
\end{tabular}

While individual abilities elementary school students in speaking skill can be seen from Table 7: Person Measure.

From the table, it is known the value of the standard deviation is 0,58 . The standard deviation value when combined with the average value of logit (mean) by 0.87 then the speaking skill of elementary school students can be grouped into categories abilities high (greater than 0.87 $+0.58=1.45$ ), moderate abilities category (between $0.87+$ 0.58 and 0.87 to 0.58 or 1.45 and 0.29 ), and lower abilities category (less than $.87-.58=0.29$ ). Thus, the limit value for the category abilities logit height is more than 1.45 , the abilities category is beginning to 0.29 up to 1.45 , and the low abilities category is less than 0.29 .

By looking at the value of each person logit elementary school students in Table 7 Measure column, speaking skill of elementary school students in Tasikmalaya, Indonesia of participants 90 people, it is known there are 14 people $(15.5 \%)$ were categorized as high abilities, category abilities were there 63 people (70\%), and 13 (14.4\%) lower abilities category

\section{Discussion}

The instrument has a function as the revealer of a fact into the data, if the instruments used are valid and reliable and has a level of difficulty, distinguishing features and a good distractor will obtain data by the real situation on the ground [23]. Teachers can require an instrument to assess the ability of students [24]. Via speaking skill so that individuals can be formulated through the instrument to reveal the speaking skill of the individual. Instrument speaking skill is defined as a measurement or parameter determining the quality and competence of individuals based on indicator determined. The results of the assessment instrument can then be used for teachers to develop students' speaking skill by looking at the indicators that have been able and not yet able of students in speaking skill. Assessment can provide feedback to teachers to enhance the planning and learning process based on the data obtained is about the weaknesses and strengths of students [25].

\subsection{Reliability and Validity of Development of Speaking Skill's Instrument}

The development of instruments in this study is derived from the definition according to Siti Halidjah speaking skill. Siti Halidjah defines talk is the ability to express things that are present in everyday life verbally with ease and fluency in place that is understood by the other person. Components that need to be considered in evaluating speaking skill, namely: aspects of language, understanding of the contents of the conversation, the conversation organization, and kinesik [26]. Then the components of speaking skill by Siti Halidjah developed by other literature, 
so we get the following: (1) linguistic aspects include (a) the accuracy of the voice; variations in speech rate, loudness (b) placement of tone pressure; high-low sounds correspond to emotional messages (c) choice of words (diction) are grouped in concrete words, connotative words, greeting words, foreign words, a loan word, vocabulary vernacular vocabulary[27]; and (d) the target accuracy talk [28], [29], (2) understanding the content of the conversation is the speaker mastery of messages to be delivered so that the listener can understand the message, characterized by (a) understanding of the speaker of the messages to be delivered, (b) a message that the speaker is correct, accurate, complete ; ( c) listeners understand the message delivered to the speaker, (d) know the purpose of the talks in the form of one or more of: notifying and reporting (to inform), entertain and amuse (to entertain), as well as to persuade, invite, urgent and convincing (to persuade)[11], [28], [30], (3) Organization of talks related to spatial order of presentation of the talks, including (a) use their own words[11], [31], [32], (4) kinetic aspect is the use of facial expression and movement of limbs speaker can help listeners better understand the conversation, including: (a) eyes, (b) movements of the hands and feet which support[26], [28], [33].

Based on the analysis of the instruments used unidimensionality construct truly measure the variables: students' speaking skill in elementary school. From the summary statistic shows that the grains of the items in the instrument, belonging to the category of nice but the consistency of the overall respondents categorized so weak that the interaction between the person with a grain of items as a whole including the category enough. The results of item fit analysis that the 15 items students' speaking skill in elementary school declared fit in the sense of normal function and can be understood correctly by elementary school students and can measure what should be measured in this case is the speaking skill. After Rating scale analysis of response options $1,2,4$, and 5 it can be understood by the participants, while the third answer choice is less understandable or confusing students. Therefore, suggested alternative answers, not 5 but simply four only.

\subsection{Speaking Skill Elementary School Students}

Rash analysis of this model is found (1) reliability rash abilities model in analyzing the elementary school students' speaking skill by speaking skill development instruments, (2) developing an elementary school students' speaking skill based on the analysis of models rash difficulty speaking skill indicators.

Rash model can demonstrate the ability of students in speaking skill based testing instrument has been developed. This is evidenced by the results of the analysis of speaking skill base in Tasikmalaya, Indonesia namely School of participants 90 people, it is known there are 14 people $(15.5 \%)$ were categorized as high abilities, category abilities were there 63 people (70\%), and $13(14.4 \%)$ lower abilities category. And maps wright showed 45 out of 90 students $(50 \%)$ of elementary school students in Tasikmalaya, Indonesia have the speaking skill over the difficulties 15 indicators of speaking, meaning that 45 students will not have difficulty in speaking by 15 items and they skillfully talk with 15 indicators set well. In addition, 85 students (94, 4\%) having an average attainment skilled in speaking are above the average standard level of difficulty speaking, two students $(2.2 \%)$ having an average achievement equivalent to the average level of difficulty speaking skill items. There are 3 students $(3.3 \%)$ who have difficulty achieving the standard below average speaking skill. Thus the rash model can be used by teachers to see the students' skill in speaking skill.

Following the background of this research that learning to speak is still negligible at elementary school level because the majority of elementary school teachers did not know what to teach and how to teach speaking skill in students [4]. Through the analysis rash model to the development of instruments visible indicators that need to be taught to students. It is because of rash models can generate the most difficult indicator grouping up is very easy for students so teachers can have an understanding of the skill that need to be improved in students.

In this study, indicator category very difficult, which is item number P1 (I speak the emphasis on the important parts), P8 (I did not forget the message that should be conveyed when speaking), P15 (I use hand gestures and walks that support my message to). Based on this it is seen that students' difficulties in distinguishing between information that is important to the usual, do not understand the message to be delivered so forget the message that must be delivered as well as still a tendency embarrassed when speaking in public which resulted in the movement of the body that supports the message does not do the students. It shows that the students are still difficulties in the use of linguistic and body language.

The modalities of speech are intonation, facial expressions, hand gestures and body movements that correspond to the message and naturally affects the speaker and receiver [33]. In addition, self-confidence effects on speaking skill and to improve students' confidence in speaking in various situations can be created through training that helps students prepare to speak, through good preparation can minimize anxiety in students [34]. Reading and talking are interconnections, if student always reading he/she will be able to speak fluently and accurately in expression [9]. Speaking skill can also be created through the competency of teachers to create a classroom to encourage students to develop their potential in speaking is to involve active student learning such as practicing talking with their friends without worrying about whether they say is wrong or not so as to increase their confidence in speaking [5], [35]. Thus, students need to be trained to familiarize themselves with the confidence to speak and 
read.

Through linguistic speaker can use the speed and pressure on certain parts of speech, volume and varying speed and using signs that will support when interacting [36]. When someone speaks using pressure, tone and intonation clearly and precisely will lead to ease the listener to understand the message delivered speakers that convey the main phrases with the obvious to the listener is very important when speaking [37]. Also, the rigid body motion will give the impression that boring and uninteresting when speaking [38]. The development of speaking skill in elementary school students emphasizes the choice of words, intonation, and expression [39]. Thus, if students are trained in linguistic skill and body language then he would be able to convey a message with clear, concise and interesting.

While the category is very easy there are three items, namely the number P11 (I speak has one goal between informing and reporting (to inform), entertain and amuse (to entertain), as well as to persuade, invite, urgent and convincing (to persuade)), P7 (I adjust the language used by the listener Language), P4 (I use a low voice when the usual message or something that is reasonable). Based on that shows that they have a purpose in speaking, can adjust the language used by the listener language and low noise when the message that ordinary reasonable or something more controlled than when sad melancholy sound, high sound when a message containing anger.

Therefore, based on the development of instrument speaking skill and analysis Rasch models found that teachers can develop the speaking skill of elementary school students by enhancing return students' speaking skill in using the emphasis on the important parts, the understanding of the messages to be delivered with reduced forget the messages to be delivered and that is the aspect kinesic using hand gestures and walks that support the message conveyed.

\section{Conclusions}

Based on the results of the collection, processing, and analysis of data on development of speaking skill's instrument in elementary schools can be summarized as follows: a) develop speaking skill outlined in the instrument to assess the skill of speaking individuals. b) In general, the development of speaking skill's instrument in the category of nice and constructs used instruments measure one variable that is the speaking skill of elementary school students so that they can measure the extent of students' skill in speaking, it means the development of the instrument in this study can be used to evaluate elementary school students' speaking skill. c) speaking skill of students in elementary schools need to be improved in using the emphasis on the important parts, the understanding of the messages to be delivered with reduced forget the messages to be delivered, and aspects kinesic using hand gestures and walks that support the message conveyed. d) Rash model can be used by teachers to analyze abilities evaluate students' speaking skill and speaking skill of elementary school students through the difficulty level indicator in the instrument speaking skill.

\section{Acknowledgments}

Thanks to lecturers and tutors who have given direction, to the Layungsari Elementary School and Balandongan Elementary School who have been willing to engage in research, the friends who have help and support in the drafting process.

\section{REFERENCE}

[1] N. M. Sugandhi, A. Saomah, A. H. Zahirah, M. Solehuddin, and D. Suryana, "The profile of prosocial behavior in elementary school children," Int. J. Sci. Technol. Res., vol. 9, no. 2, pp. 790-792, 2020.

[2] T. Wörtwein, L. P. Morency, M. Chollet, R. Stiefelhagen, B. Schauerte, and S. Scherer, "Multimodal public speaking performance assessment," ICMI 2015 - Proc. 2015 ACM Int. Conf. Multimodal Interact., pp. 43-50, 2015.

[3] I. Saripah, M. Supriatna, B. Oktaviani, M. Solehuddin, and D. Suryana, "The profile of interpersonal communication skills in elementary school students," Int. J. Sci. Technol. Res., vol. 9, no. 2, pp. 4975-4979, 2020.

[4] P. Tambunan, "Pembelajaran Keterampilan Berbicara di Sekolah Dasar," pp. 1-11, 2018.

[5] N. Argawati, “Improving Students' Speaking Skill Using Group Discussion (Experimental study on the First Grade Students of Senior High School)," Eltin Journal, J. English Lang. Teach. Indones., vol. 2, no. II, pp. 74-81, 2014.

[6] G. Liao, "Improvement of Speaking Ability through Interrelated Skills," English Lang. Teach., vol. 2, no. 3, pp. 11-14, 2009.

[7] N. O. M. Al-Tamimi and R. A. Attamimi, "Effectiveness of Cooperative Learning in Enhancing Speaking Skills and Attitudes towards Learning English," Int. J. Linguist., vol. 6, no. 4, pp. 27-45, 2014.

[8] Agus, "Motivating Students's Speaking Skill Through Simulation In English for Spacific Purposes," Madsa, Tak., vol. 3, pp. 1-8, 2012.

[9] C. T. Mart, "Developing Speaking Skills through Reading," Int. J. English Linguist., vol. 2, no. 6, pp. 91-96, 2012.

[10] F. Pattanpichet, "English Speaking Achievement," J. Coll. Teach. Learn., vol. 8, no. 11, pp. 1-10, 2011.

[11] T. Oradee, "Developing Speaking Skills Using Three Communicative Activities (Discussion, Problem-Solving, andRole-Playing)," Int. J. Soc. Sci. Humanit., vol. 2, no. 6, 
pp. 533-535, 2013.

[12] A. Saomah, D. Suryana, and O. A. Adzani, "Aggressive behavior in elementary school," Int. J. Sci. Technol. Res., vol. 9, no. 2, pp. 1891-1894, 2020.

[13] P. A. Bukian, "Pengembangan Instrumen Penilaian Kinerja Keterampilan Berbicara dalam Pembelajaran Bahasa Indonesia," IKA, vol. 15, no. 2, pp. 133-145, 2017.

[14] J. Sabaryati, M. Isnaini, and I. Ilham, "Pelatihan Aplikasi Permodelan Komputer Berbasis Rash Model Untuk Assesment Pendidikan Bagi Guru-Guru Di Ponpes Nurul Haramain Putra Narmada," SELAPARANG J. Pengabdi. Masy. Berkemajuan, vol. 2, no. 1, pp. 38-42, 2018.

[15] A. Kurniawan, M. Rusdi, and J. Marzal, "Pengembangan Modul Pedoman Guru dalam Mendesain Instrumen Penilaian Matematika Berbasis Pemecahan Masalah Matematika," Edumatika J. Ris. Pendidik. Mat., vol. 2, no. 1, p. 15, 2019.

[16] K. A. Levin, "Study design III: Cross-sectional studies," Evid. Based. Dent., vol. 7, no. 1, pp. 24-25, 2006.

[17] Nurhudaya, A. Taufik, E. S. Yudha, and D. Suryana, "The Raven's advanced progressive matrices in education assessment with a Rasch analysis," Univers. J. Educ. Res., vol. 7, no. 9, pp. 1996-2002, 2019.

[18] A. H. G. S. Van Der Ven and J. L. Ellis, "A Rasch analysis of Raven's standard progressive matrices," Pers. Individ. Dif., vol. 29, no. 1, pp. 45-64, 2000.

[19] S. Rahayah Ariffin, B. Omar, A. Isa, and S. Sharif, "Validity and reliability Multiple Intelligent item using Rasch measurement model," Procedia-Soc. Behav. Sci., vol. 9, pp. 729-733, 2010.

[20] D. R. Lubans et al., "A systematic review of the validity and reliability of sedentary behaviour measures used with children and adolescents," Obes. Rev., vol. 12, no. 10, pp. 781-799, 2011.

[21] P. Hagell, “Testing Rating Scale Unidimensionality Using the Principal Component Analysis (PCA)/\&lt;i\&gt;t\&lt;/i\&gt;-Test Protocol with the Rasch Model: The Primacy of Theory over Statistics," Open J. Stat., vol. 04, no. 06, pp. 456-465, 2014.

[22] R. S. Ilhami and D. Rimantho, "Jurnal Optimasi Sistem Industri Penilaian Kinerja Karyawan dengan Metode AHP dan Rating Scale," J. optimasi Sist. Ind., vol. 2, pp. 150-157, 2017.

[23] Z. Arifin, "Kriteria Instrumen dalam suatu Penelitian," $J$. Theorems (the Orig. Res. Math., vol. 2, no. 1, pp. 28-36, 2017.

[24] Saheri, K. I. Supardi, and S. Haryani, "Pengembangan Instrumen Penilaian Keterampilan Berpikir Kritis Siswa SMAMelalui Model Pembelajaran Berbasis Masalah Materi Larutan Penyangga," J. Innov. Sci. Educ., vol. 5, no. 2, pp. 152-162, 2016.

[25] D. Ariani, E. Saptaningrum, and J. Siswanto, "Instrumen Penilaian Keterampilan Kerja Ilmiah pada Pembelajaran Fisika Berbasis Inquiry," J. Penelit. Pembelajaran Fis., vol. 7, no. 2, pp. 109-117, 2017.

[26] S. Halidjah, "Evaluasi Keterampilan Berbicara dalam
Pembelajaran Bahasa Indonesa," J. Visi Ilmu Pendidik., pp. 259-268, 2010.

[27] A. K. Rizqi, S. Suwandi, and S. Raheni, “Aspek Diksi serta Nilai-nilai Pendidikan Karakter dalam Novel AYAH Karya Andrea Hirata," BASASTRA, vol. 6, no. 1, pp. 19-37, 2018.

[28] A. Aini, A. Andayani, and A. Anindyarini, "Metode Mind Mapping Untuk Meningkatkan Keterampilan Berbicara Siswa Sekolah Dasar," J. Penelit. Bahasa, Sastra Indones. dan Pengajarannya, vol. 1, no. 1, pp. 35-45, 2012.

[29] A. Kuśnierek, "World Scientific News WSN.," World Sci. News, vol. 7, no. 7, pp. 73-111, 2015.

[30] S. Ningsih, "Peningkatan Keterampilan Berbicara melalui Metode Bercerita Siswa Kelas III SD Negeri 1 Beringin Jaya Kecamatan Bumi Raya Kabupaten Morowali," J. Kreat. Tadulako Online, vol. 2, no. 4, pp. 243-256, 2013.

[31] A.. Fallis, "Pengaruh Media Film Animasi Fiksi Islami untuk Meningkatkan Kemampuan Menyimak dan Berbicara Siswa Sekolah Dasar," J. Chem. Inf. Model., vol. 53, no. 9, pp. 1689-1699, 2013.

[32] D. S. Kuning, “Technology in Teaching Speaking Skill," $J$. English Educ. Lit. Linguist., vol. 2, no. 1, pp. 50-59, 2019.

[33] M. Busà, "Sounding natural: improving oral presentation skills," Lang. Value, vol. 2, no. 2, pp. 51-67, 2010.

[34] K. Boonkit, "Enhancing the development of speaking skills for non-native speakers of English," Procedia - Soc. Behav. Sci., vol. 2, no. 2, pp. 1305-1309, 2010.

[35] A. Asakereh and M. Dehghannezhad, "Student satisfaction with EFL speaking classes: Relating speaking self-efficacy and skills achievement," Issues Educ. Res., vol. 25, no. 4, pp. 345-363, 2015.

[36] Batmang, "Kesalahan Fonologis dalam Berbicara Bahasa Arab pada Mahasiswa MMatrikulasi STAIN Kendari," Al-Izzah, vol. 8, no. 1, pp. 19-38, 2013.

[37] Y. Mulyati, "Hakikat Keterampilan Berbahasa," pp. 1-34, 2015.

[38] M. Maisarah, "Aplikasi komunikasi non-verbal di dalam kelas," unipdu, pp. 25-29, 2019.

[39] E. P. Permana, "Pengembangan Media Pembejaran Boneka Kaus Kaki Untuk Meningkatkan Keterampilan Berbicara Siswa Kelas Ii Sekolah Dasar," Profesi Pendidik. Dasar, vol. 2, no. 2, pp. 133-140, 2015. 